\title{
Espaços de participação e escolarização de trabalhadores rurais: construção ou destituição do direito à educação no campo?
}

\author{
Sônia Pereira \\ Universidade Federal do Ceará, Programa de Pós-Graduação em Educação Brasileira
}

\section{Introdução}

As histórias de escolarização de trabalhadores rurais permitem afirmar que a educação de jovens e adultos no campo se faz com precariedades de toda sorte e, ainda que a vida política do município seja vibrante e conte com a presença ativa dos trabalhadores rurais, ${ }^{1}$ os espaços participativos como associações, sindicatos e especialmente os conselhos não têm sido efetivamente incorporados ao universo desses trabalhadores para a busca de soluções ou para exercer o controle social sobre as políticas e os programas educacionais. A educação de jovens e adultos do campo tanto permanece fora da agenda desses espa-

${ }^{1}$ Ao empregar a denominação "trabalhadores rurais", refiro-me à população camponesa que em sua maioria não possui terra ou possui pequena parcela que mal permite a reprodução social. Trata-se de camponeses ou agricultores familiares que utilizam a força de trabalho familiar para sua reprodução, que se inserem no mercado de forma subalterna, pagando renda para o uso da terra e recorrendo a pequenas ocupações ou biscates para a complementação da renda familiar. ços de participação como somente de forma secundária é tratada como questão de Estado.

Este trabalho busca analisar como as ressonâncias das "mensagens" que prometem "educação para todos" são vivenciadas pelos jovens e adultos do campo. Tais mensagens proclamam a educação como um direito, inclusive dos trabalhadores rurais, sujeitos que carregam historicamente a tradição perversa do analfabetismo; e a perversidade é agravada, pois tal situação é tomada quase como um fenômeno natural. ${ }^{2}$

${ }^{2}$ A taxa de analfabetismo da população de 15 anos ou mais no Brasil é significativamente mais alta na zona rural do que na urbana. Enquanto nas cidades, em 2000, a taxa era 10,3\%, no campo alcançava $29,8 \%$. Os índices apresentam um quadro mais grave ao observarmos o analfabetismo no Nordeste: $19,5 \%$ na zona urbana e 42,7\% na rural (Brasil, 2004, p. 14). Ainda que essa leitura não se realize em negativo - não em termos de analfabetismo, mas de níveis de alfabetismo - as desigualdades regionais e sociais reproduzem-se; estudo realizado pelo Instituto Paulo Montenegro e pela Ação Educativa confirma os índices que permitem compor um quadro no qual diferenças de renda e de regiões influenciam tais níveis (Instituto Paulo Montenegro, Ação Educativa, 2001, p. 19 e 23; Di Pierro, 2003). 
Trata-se, no entanto, de uma condição social de homens e mulheres que parecem freqüentemente identificá-la com incapacidades próprias, individuais, e raramente com irresponsabilidade ou inoperância do Estado e de seus governantes na destinação de recursos financeiros e humanos para que o direito à educação seja assegurado; tampouco é vista como conseqüência de fragilidades na organização da sociedade na demanda para tornar efetivo o direito inscrito na Carta Constitucional de 1988. O presente estudo também tem o intuito de analisar aspectos que contribuam para uma compreensão do processo de construção do direito à educação no campo.

A educação tem sido apresentada por governantes e tomada pela sociedade civil como uma fórmula que encerra o poder quase mágico de proporcionar ao cidadão a mobilidade social e a progressiva melhoria nas condições de vida, posto que no estudo residiria a possibilidade de o indivíduo alcançar melhores oportunidades no mundo do trabalho, contribuir para o desenvolvimento econômico-social e participar mais ativamente da vida política nacional.

Essa miragem atravessa todo o espectro social brasileiro, no campo e nas cidades, no sertão, no litoral ou nas serras. Os portadores de tais discursos e as práticas que por eles se orientam encontram-se não somente no campo governamental. Podem ser igualmente identificados do lado da sociedade civil organizada: nas organizações não-governamentais, nas associações de pequenos agricultores ou no sindicato de trabalhadores rurais os quais parecem não escapar das teias do otimismo (pedagógico?) em curso. ${ }^{3}$

${ }^{3}$ Não pretendo, com tais afirmações, minimizar a importância da educação - escolarização, alfabetização ou letramento - na formação humana. O processo educacional, quando considera as especificidades e singularidades culturais da população, constituise efetivo instrumento de crescimento individual e coletivo dos sujeitos envolvidos, abre oportunidades profissionais e pode significar uma das vias de mobilidade social. Essa compreensão, ainda que aceita no mundo contemporâneo, sofre questionamentos sobre a posição de superioridade dos indivíduos letrados, como
Atendendo às demandas educacionais, o Estado vem ofertando, nos dez últimos anos, programas de alfabetização e de ensino fundamental e médio para a população jovem e adulta do campo que não se escolarizou quando criança. Tal oferta, de modo geral, parece anunciar um novo tempo, prometer vida mais farta, apontar perspectivas profissionais, especialmente aos jovens. A discrepância entre o discurso e a realidade prática, porém, propõe questões que merecem ser investigadas. Como afirmar que o direito à educação está sendo instituído e afirmado no mundo rural se o que se observa, à primeira vista, são precariedades de toda sorte, revelando uma "presença" estatal deficitária, uma quase ausência? Os professores são mal remunerados, o material didático é inadequado, os prédios escolares, as instalações e os equipamentos são precários e os resultados, em termos de aprendizagem, são insatisfatórios.

Em contrapartida, considerando a existência de espaços associativos que, em tese, seriam os instrumentos destinados a exercer o controle social sobre as políticas governamentais - tanto aqueles ofertados pelo Estado (conselhos gestores) quanto aqueles mais orgânicos, construídos pelos próprios trabalhadores rurais (sindicatos e associações de pequenos agricultores $)^{4}$-, coloca-se a questão: até que ponto esses espaços têm sido apropriados pela população local (dos municípios) para interferir nas políticas de educação?

Excetuando os movimentos sociais que disputam seu espaço no cenário nacional e mesmo interna-

ocorre no meio acadêmico. Há leituras outras que, embora considerem a importância da cultura letrada, reconhecem saberes e sabedoria em outras formas de expressão - como o saber da tradição de idosos de um povo -, formas, aliás, vistas como tão valiosas para uma vida digna e criativa quanto aquela (letrada). Ver acerca dessa questão artigo interessante e sensível de Munir Fasheh, traduzido por Timothy Ireland, na Revista Brasileira de Educação. "Como erradicar o analfabetismo sem erradicar os analfabetos?" (n. 26, 2004, p. 157-169).

${ }^{4}$ Ver artigo que trata da experiência participativa nesse município em Pereira (2004). 
cional, com vistas à redefinição de lugares sociais instituídos, fundando propriamente a política ${ }^{5}$ e afirmando o direito constitucional no dia-a-dia dos trabalhadores rurais - a exemplo do Movimento dos Trabalhadores Sem Terra (MST)e sua prática educacional nas áreas de assentamento e nos acampamentos -, como cogitar a possibilidade de direitos em construção se a descrição desse quadro educacional se faz, predominantemente, em negativo?

Registro "predominantemente" porque, a despeito de todas as insuficiências, os trabalhadores rurais insistem em freqüentar cursos de educação de jovens e adultos em salas de aula precárias. Lá são despendidos esforços imensos de professores das próprias comunidades rurais para que o processo de ensinoaprendizagem vingue, mas, não raro, resultam em desistências (ou exclusões) ou "analfabetismo escolar". ${ }^{6}$ Qual o significado da persistência desses trabalhadores que, ao se depararem com a impossibilidade

${ }^{5}$ Para Jacques Rancière (1996), a política funda-se no conflito, no dissenso e somente se institui quando a parcela disputada pelos "sem-parcela" altera a condição de desigualdade; sem a mudança de lugares sociais ocorre, segundo esse autor, mera administração de interesses.

${ }^{6} \mathrm{O}$ analfabetismo escolar é um fenômeno que se verifica usualmente em estudantes de escolas públicas (mas não somente nessas) na faixa etária de 7 a 14 anos, caracterizado pelo desenvolvimento insatisfatório das habilidades de leitura, escrita e compreensão. Estudos realizados em 2005, no Ceará, pelo Comitê Cearense para a Eliminação do Analfabetismo Escolar, com a participação da Universidade Federal do Ceará, revelam o seguinte quadro: $33 \%$ das crianças avaliadas - alunos da $2^{\mathrm{a}}$ série, na sua maioria, com 7 e 8 anos de idade - não conseguiram sequer ler um texto escrito e $44 \%$ não conseguiram produzir um texto escrito ou apresentaram um estágio de escrita avaliado até o nível silábicoalfabético. Os estudantes que puderam ser considerados alfabetizados nas três dimensões avaliadas, ou seja, na oralidade, compreensão e produção de texto alcançaram $16 \%$ (Marques et al., 2006, mimeo). A pesquisa traz dados que nos autorizam afirmar que, se não forem tomadas severas medidas para a oferta de uma educação de qualidade, a produção de jovens e adultos "analfabetos escolares" continua em franca expansão. de cursar a $1^{\text {a }}$ série, mantêm-se na alfabetização e, na impossibilidade de cursá-la, passam a freqüentar um nível mais avançado, mesmo que isso lhes impossibilite um aproveitamento satisfatório? ${ }^{7}$

As referências mais imediatas que norteiam uma noção de direito à educação são o artigo 205 da Constituição Federal de 1988, o qual assegura ser a "educação direito de todos e dever do Estado e da família, [...] promovida e incentivada com colaboração da sociedade, visando ao pleno desenvolvimento da pessoa, seu preparo para o exercício da cidadania e sua qualificação para o trabalho"; e o artigo 208 que garante a provisão pública de "ensino fundamental obrigatório e gratuito, assegurada, inclusive, sua oferta para todos os que a ele não tiveram acesso na idade própria" (Brasil, 1988, p.130-131). No entanto, partirei de uma concepção mais alargada do direito, compreendendo-o como relacionado não apenas às garantias formais, inscritas nas leis, mas dizendo respeito ao modo como as relações sociais estruturam-se e como a sociedade estabelece seus princípios e prioridades (Telles, 1999).

A educação, entendida como um direito constitucional e como direito a ter direitos, situa-se como uma dimensão que se relaciona com o Estado, com a política e, portanto, com a sociedade e suas características particulares. Em outros termos, para entendermos os processos educacionais, particularmente os do campo, é necessário que os consideremos com nossas próprias marcas ou características estruturais e culturais - como a convivência de tempos históricos diversos, que imprimem à nossa "modernidade" certa anomalia -, podendo-se até falar em modernização conservadora ou apontar como maior inconclusividade a estrutura fundiária, concentrada e profundamente injusta; ou, ainda, que nossa organização social é baseada em relações hierárquicas, cujo autoritarismo social "pervade" as esferas pública e privada (Dagnino, 1994; Martins, 2000).

\footnotetext{
${ }^{7} \mathrm{O}$ estudo identificou nas escolas e turmas observadas que
} os trabalhadores rurais recorrem a essa estratégia para não ficarem impossibilitados de freqüentar uma sala de aula. 
Este artigo é resultado de uma pesquisa que vem se desenvolvendo no Ceará. Em termos bastante sucintos, trata de examinar como os trabalhadores rurais inserem-se no processo de letramento, ${ }^{8}$ com foco na possibilidade de construção do direito à educação.

A investigação vem sendo realizada desde 2004 e o trabalho de campo foi efetuado no município de Baturité, no segundo semestre de 2005 e em março de 2006. Durante vários dias foram diligentemente realizadas observações em sala de aula de turmas de educação de jovens e adultos das séries iniciais $\left(1^{\mathrm{a}} \mathrm{a}\right.$ $\left.4^{\mathrm{a}}\right)$, além de turmas mistas $\left(1^{\mathrm{a}}\right.$ a $4^{\mathrm{a}}$ série, que contavam inclusive com alunos de alfabetização) e turmas de ensino médio. Foram efetuadas dezoito entrevistas com estudantes trabalhadores rurais em suas casas e em espaços públicos, como igrejas e calçadas

${ }^{8} \mathrm{O}$ artigo foi inicialmente discutido em sessão do Grupo de Trabalho Movimentos Sociais e Educação na 29a Reunião Anual da ANPEd em 2006, a partir do que tive a oportunidade de reformulá-lo, incorporando as contribuições. A pesquisa, cujo projeto original intitula-se "A construção do direito à educação: significados do letramento para trabalhadores rurais", está vinculada a uma investigação que pretende analisar os programas governamentais para a educação de jovens e adultos no campo (no Ceará). Quanto à noção de letramento, esse termo foi cunhado recentemente (anos 1980) no meio acadêmico. Trata-se de uma conceituação que compreende o uso social da palavra escrita e da leitura de forma ampla, ou seja, é uma prática social que compreende um conjunto complexo de habilidades e conhecimentos da escrita e da leitura vivenciado por grupos sociais. Magda Soares afirma que letramento é diferente de alfabetização: "ter-se apropriado da escrita é diferente de ter aprendido a ler e a escrever; aprender a ler e a escrever significa adquirir uma tecnologia, a de codificar a língua escrita; apropriar-se da escrita é tornar a escrita própria, ou seja, é assumi-la como sua 'propriedade'.” A autora amplia a conceituação, diferenciando o alfabetizado do letrado, ao afirmar que "um indivíduo alfabetizado não é necessariamente um indivíduo letrado, alfabetizado é aquele indivíduo que sabe ler e escrever; já o indivíduo que vive em estado de letramento é não só aquele que sabe ler e escrever, mas aquele que usa socialmente a leitura e a escrita, pratica a leitura e a escrita, responde adequadamente às demandas sociais de leitura e de escrita" (Soares, 2003, p. 39-40). em frente a modestos prédios comerciais da zona rural de Baturité; duas entrevistas e mais algumas conversas informais foram concedidas por diretores do Sindicato de Trabalhadores Rurais do município; e outras duas entrevistas com técnicos da Secretaria de Educação municipal, além de conversas informais e dinâmicas com professores das escolas situadas no campo desse município.

A pesquisa de campo também foi realizada na zona rural de Caucaia, município da região metropolitana, e atualmente vem desenvolvendo o trabalho de campo em outros dois municípios do Ceará. ${ }^{9}$ Este artigo, no entanto, tratará dos dados levantados em Baturité, um pequeno município situado na região serrana do estado, a 100 quilômetros da capital. Como trago para debate a reflexão produzida a partir dos dados de só um município, não tenho a pretensão de generalizar seus achados, mas produzir um estudo que reúna elementos descritivos e analíticos que contribuam para a compreensão da diversidade e complexidade das questões relacionadas ao direito à educação de jovens e adultos no campo.

Baturité possui cerca de 30 mil habitantes dos quais um terço vive no campo e tem sua ocupação no trabalho agrícola, especialmente na fruticultura (banana), milho e feijão. O município caracteriza-se pela estrutura minifundiária e considerável parcela de trabalhadores não possuem terra alguma; produzem, portanto, na condição de meeiros ou, dependendo do cultivo, pagando outra porcentagem (1/3 ou 1/4 da produção) de renda pelo uso da terra de outros.

O foco da análise incide sobre os sujeitos protagonistas do processo educativo: os trabalhadores rurais jovens e adultos das comunidades do Sítio Candeia Boa Vista, Sítio Jesuítas e Sítio São Pedro. Nessas três comunidades, além dos trabalhadores que freqüentavam a escola, foram entrevistados outros que

${ }^{9}$ Todo o processo de investigação contou com a participação dos bolsistas do grupo de pesquisa "Movimentos sociais, educação popular e escola", cadastrado no diretório de pesquisa do $\mathrm{CNPq}$, aos quais deixo aqui o registro de minha gratidão pela oportunidade de aprendizados e pelos esforços empreendidos. 
haviam temporariamente interrompido os estudos e não freqüentavam a escola no momento; todos já tinham passado por experiências educacionais em programas governamentais, tais como: Mobral (anterior aos anos 1990), Alfabetização Solidária (anos 1990), Brasil Alfabetizado (2005) e programas de educação de jovens e adultos (Ensino Fundamental I $-1^{\text {a }}$ a $4^{\mathrm{a}}$ séries, e II $-5^{\mathrm{a}}$ a $8^{\mathrm{a}}$ séries, e Ensino Médio). Outros trabalhadores rurais entrevistados continuavam a freqüentar os cursos dos programas de Ensino Fundamental I e II. A análise restringe-se, aqui, aos depoimentos dos estudantes que passaram por essas experiências de alfabetização e freqüentam o ensino fundamental I. ${ }^{10}$

$\mathrm{O}$ artigo estrutura-se em quatro eixos: no primeiro, busca reconstituir a história de escolarização dos sujeitos da pesquisa; no segundo, estabelecer relações entre as condições socioeconômicas dos trabalhadores rurais, seus espaços associativos e os programas de educação; e, em termos conclusivos, os itens três e quatro registram análise sucinta acerca da pergunta central que norteia a pesquisa: o processo de escolarização de jovens e adultos no campo movimenta-se na direção da construção ou da destituição do direito à educação?

\section{Escolarização: um roteiro de dificuldade e destituição}

A similitude nas falas dos trabalhadores rurais é $\mathrm{o}$ aspecto que chama a atenção desde o início do trabalho de campo e no exame de depoimentos e na observação realizada. Penso que se, para discorrer sobre a história de vida dos estudantes entrevistados, eu fizesse uso da metáfora da produção artística de gravura em madeira, os traços que brotariam seriam tortuo-

${ }^{10}$ Considerando que a pesquisa constatou que os programas governamentais são ofertados de forma irregular e descontínua e, não raro, como campanhas, entendo ser inadequado referir-me a eles usando a denominação "políticas públicas”, posto que essas compreendem planejadas, sistemáticas e contínuas ações governamentais sos, inscrevendo em uma só matriz dois significados: a dificuldade e a destituição.

$\mathrm{O}$ primeiro deles diz respeito à dificuldade de conciliar a lida do campo e a lida do estudo que, na pesquisa, sempre comparecem como práticas incompatíveis no passado dos adultos. Tal dificuldade expressa-se nos depoimentos como um quase lamento, tanto de jovens quanto dos trabalhadores mais velhos. Lamento que tem início já nos tempos de meninos. Solicitados a falar de suas vidas desde a infância, invariavelmente começam suas histórias referindo-se ao trabalho e não ao estudo:

Eu tenho sofrido tanto na minha vida. Eu, desde pequena, trabalho mais meu pai. Meu pai morreu, eu fiquei pra criar 13 filhos. E criei tudo, passando fome. Trabalhando no cabo da enxada para dar de comer a 13 filhos que meu pai deixou. (Dona Nenê, 61 anos, da comunidade de Candeias, cursando Fundamental I - $1^{\mathrm{a}}$ e $2^{\mathrm{a}}$ séries)

A minha vida foi não muito boa, porque eu fiquei sem minha mãe aos seis anos (..) nós morava no sertão, aí meu pai veio embora de lá...passei a viver com meus avós...Desde a idade que eu completei dez anos que eu comecei a trabalhar na agricultura. Na agricultura eu só não planto mesmo é a cana, mas arroz, feijão, fava, milho, feijão de arrancar, tudo isso eu planto (...) Estudei, mas o meu estudo era assim, quando começava o inverno, meu pai tirava eu da sala para ajudar no roçado porque ele não tinha condição de pagar uma pessoa, aí me tirava da escola pra plantar feijão, mandioca, milho, fava, aí quando terminava tudinho, quando a gente terminava de limpar, chegava o verão, a gente colhia, e eu voltava pra aula de novo, aí meu estudo foi bem pouquinho. (Dona Toinha, 41 anos, Sítio São Pedro, fora da escola)

Dona Nenê em sua infância foi à escola, mas como milhares de iguais não suportou o trabalho e o estudo juntos. Voltou a estudar aos 16 anos, parou, depois retornou aos 60 na turma de Fundamental I. Não sabe em que série se encontra. Só sabe que pretende aprender a ler "por cima", diz, correndo os dedos por cima de palavras imaginárias sobre a mesa. É 
assim que se refere à leitura sem dificuldades ou à leitura que gostaria de alcançar, sem precisar primeiro juntar as letras para, em seguida, juntar as sílabas e as palavras, conforme ensina a professora. Ela quer aprender a ler "corrido" para poder ensinar o catecismo aos netos.

Dona Toinha também teve roteiro semelhante: parou de estudar de vez, como diz, aos 18 anos, retornou algumas vezes somente após completar 23, freqüentando o Mobral, depois o Alfabetização Solidária. Esse, ela diz ter abandonado porque nasceram as gêmeas, que faleceram com menos de dois meses... e agora, aos 41 anos, está esperando nova turma para retomar os estudos, mas somente depois que outro filho, nascido após as gêmeas, estiver mais crescido. Sabe ler, mas escrever diz não saber. Assim se expressa:

Eu leio, mas não escrevo nada. Ave Maria, eu tinha muita vontade de escrever; o tanto que eu leio se eu escrevesse era muito bom! [...] Eu não leio muito, não, pouquinho, assim três ou quatro nomezinhos. Assino bem o nome. (Dona

Toinha, 41 anos, Sítio São Pedro, fora da escola)

Essa trabalhadora rural fica muito comovida, com os olhos molhados, ao falar da frustração de não poder sequer "escrever uma nota no dia das mães para colocar na parede". Outra coisa que a incomoda é não ter privacidade quando quer escrever cartas para a cunhada, que mora em Horizonte; não sabendo escrever, precisa pedir que outra pessoa o faça.

Ainda retenho na memória a voz de Sr.Vicente, do Sítio São Pedro, 48 anos, pai de seis filhos, que diz se sentir muito velho para aprender com essa idade. E assim começa a sua história: "Minha história de menino é só sofrimento, só trabalho.” Não estudou quando menino. Lamenta: "Nunca tive esse gosto de meus pais me botar na escola; via meus primos irem para a escola e eu me arrumava para o serviço". Seus filhos, todos os seis, hoje estudam porque entende que será melhor para eles; o mais velho, porém, "passou dez anos estudando e não aprendeu nada". (Sr. Vicente, 48 anos, Sítio São Pedro, não-alfabetizado, mas cursando Fundamental I - $1^{\mathrm{a}}$ e $2^{\mathrm{a}}$ séries)
Essas são histórias de destituídos do direito à escolarização quando crianças. Pergunto: onde se situam os sujeitos entrevistados pela pesquisa na escala das prioridades governamentais?

Avalio que os trabalhadores rurais, por não estarem envolvidos em formas contundentes de organização política, não são tomados como população que está a demandar atendimento prioritário, ao menos no que concerne à educação, tornando verdadeira a assertiva de que só alcançam direitos os grupos sociais mobilizados, pois aqueles que não se mobilizam não são vistos, nem ouvidos, e, então, só lhes resta acatar decisões.

Como forma contundente, não me refiro somente a mobilizações significativas, como as protagonizadas pelo MST, com suas experiências educativas em assentamentos e manifestações de rua. Remeto à reflexão sobre as possibilidades que se perdem ao não serem utilizadas as potencialidades críticas que guardam os espaços como sindicatos, conselhos gestores, fóruns e associações; espaços que muitas vezes não são apropriados com a justificativa de serem manipulados por prefeitos e políticos locais. $\mathrm{Na}$ verdade, o sinônimo para contundente, aqui, seria aquele incansável trabalho político-educativo, silencioso, presente nas lutas sociais; a invenção cotidiana da contrahegemonia que aparece principalmente em momentos de grandes mobilizações.

Com o foco de análise no Estado e no homem comum, que senta em bancos escolares para estudar, permito-me então um parêntese para refletir sobre o programa Brasil Alfabetizado. Este faz parecer em sua peça publicitária, veiculada no rádio e na televisão, muito viva e simpática, que o processo educacional de populações que não se escolarizaram no tempo devido pode se efetivar com grande facilidade. Posso supor, inclusive, que sugere facilidade de acesso aos recursos financeiros e que esses chegam à ponta do sistema educacional.

Na prefeitura de Baturité, no entanto, não há sinal dessa suposta facilidade. Pelo contrário, é possível ouvir queixas que se referem à exigüidade de recursos financeiros; queixas - e foi possível verificar - 
que desencadeiam, por sua vez, parte das precariedades observadas nas experiências educacionais das comunidades visitadas. Além de insuficiências várias - de material didático, estrutura física e equipamentos escolares, transporte etc. - a remuneração que recebem as professoras (em forma de bolsa e não de salário) não alcança o salário mínimo: é R \$207,00.

As histórias aqui relatadas não justificariam políticas consistentes, em cujas linhas de ação constasse efetiva preparação de professores e, ainda, que assegurassem que as remunerações docentes não tivessem o caráter de bolsas de ajuda de custo, como vem ocorrendo no município e nessa localidade em particular? E não deveriam as políticas considerar as reais condições, histórias e necessidades atuais desses homens e mulheres?

Tal quadro, em clara discrepância com o discurso governamental, certamente está relacionado ao interesse do governo federal em melhorar os índices de alfabetismo; não se pode negar que esforços são empenhados quando programas são implementados após disputas acirradas no interior do governo, seja na esfera federal, seja na estadual ou municipal. No entanto, tal interesse está preso à estratégia da reforma educacional que vem operando a massificação do ensino fundamental - e especialmente a modalidade de educação de jovens e adultos - sem o aporte de novos recursos, trazendo como resultado o comprometimento da qualidade (Ximenes, 2006). Tal estratégia - que busca atender aos imperativos de ordem econômica e da política "global" para a qual o Estado é tomado como mero instrumento para viabilizar a submissão da nação aos ajustes fiscais e aos interesses da economia financeirizada - deveria ser objeto de reflexão e crítica dos referidos espaços de organização, sob pena de vermos reedições do quadro atual nas futuras administrações.

\section{Espaços associativos e programas educacionais}

Merecem exame os fatores relacionados à renda familiar e à situação dos trabalhadores rurais no que se refere à propriedade da terra, pois são esses ele- mentos que nos permitem apreender a especificidade do estudante trabalhador rural.

A renda é pouca, mal dá para a sobrevivência. A pobreza extrema, visível, pode ser identificada no modo de vida, na precariedade das moradias, nas vestimentas e parece ser a concretização da destituição de qualquer direito humano. Os homens e mulheres que residem nas comunidades anteriormente mencionadas não são, em sua maioria, proprietários das áreas nas quais trabalham. Pagam renda: a meia, uma terça e também uma quarta parte do que produzem. Aqueles que possuem terra própria reinam sobre, no máximo, três hectares - terra ínfima para qualquer exercício de autonomia na vida do camponês nordestino. Em Baturité, região serrana, pedregosa e acidentada, três hectares é também parcela minúscula para produzir. Daí, suponho e outras pesquisas confirmamno, a autonomia, seja na produção, seja no âmbito político, é uma empreitada sem perspectivas, a menos que os espaços associativos se empenhem sobremaneira em politizar a vida cotidiana dessas pessoas. $\mathrm{E}$ as associações dos pequenos agricultores e o sindicato bem que se esforçam para tal! (Pereira, 2004).

Solicitado a falar de um sonho que carrega em sua vida, Sr. Vicente, do Sítio São Pedro, trabalhador sem terra que conseguiu construir sua casa no único hectare que possui, confessou:

Sonhos, tenho muitos, só que é difícil realizar... Meu sonho é esse, que Deus me alcançasse um meio de vida pra não ser humilhado. Trabalhar pra gente mesmo. Tendo terra fica mais fácil. Mesmo sem estudo, dava pra viver melhor, tranqüilo.

O sentimento de humilhação que expressa e pesa sobre sua vida é comum também nos relatos de vida de outros; e a terra para trabalhar liberto é o sonho mais recorrente.

A outra face da expropriação, a venda da força de trabalho, condição que se lhe apresenta como alternativa de renda, tampouco pode ser utilizada, pois não há oferta de emprego na região. Tal compreensão da realidade local também pode ser verificada entre os pró- 
prios entrevistados: não há oportunidades, não há emprego; e essa é uma dificuldade enfrentada especialmente pelos jovens. Os trabalhadores rurais ainda expressam certa clareza na relação que estabelecem entre trabalho e estudo. Afirmam genericamente que o estudo é muito importante porque propicia maior conhecimento, porém, contraditoriamente, sugerem tratar-se de conhecimento que não tem valia, pois apontam o grande número de jovens da comunidade que terminou o ensino médio e encontra-se desempregado.

Essa é uma questão inquietante. Quem não valoriza o conhecimento: o Estado? O mercado? A própria sociedade civil da qual fazem parte esses estudantes trabalhadores rurais - as associações de agricultores? Então, escolarização não é sinônimo de conhecimento que propiciaria qualificação para o trabalho nem no campo nem na cidade? De qual conhecimento está a se tratar aqui? Arrisco-me a afirmar que todos esses espaços - com exceção do mercado - estão imbuídos de uma miscelânea conceitual e política que contribui mesmo para produzir mais confusão sobre a necessidade do estudo. O conhecimento ou estudo (que aqui equivale à escolarização) ora é tomado como bem social ou porta que se abre para oportunidades de trabalho, como direito que viabilizaria a mobilidade social; ora é visto como recurso inútil que não oferece grandes oportunidades de mudanças individuais, mas que vale a pena, pois sempre se aprende um pouco mais.

O discurso do Sindicato dos Trabalhadores Rurais de Baturité (STR) ${ }^{11}$ e das Associações de Pequenos Agricultores - espaços associativos que, na região e nesse município em particular, mais organica-

${ }^{11}$ Discute-se nos movimentos sociais do campo o papel dos sindicatos, atribuindo-lhe alguns setores o caráter de aparelho burocrático, cuja forma de atuação política seria tradicional. No entanto, tal visão parece-me estreita, se considerarmos que a história do movimento sindical no Nordeste cumpriu importante papel na reestruturação das relações de trabalho e de produção, essas, sim, profundamente arcaicas até meados dos anos 1970 quando a moradia e a meação eram formas predominantes de explora- mente, vinculam-se às necessidades e interesses da população do campo - caracteriza-se por idéias fragmentadas, contraditórias. Tanto parece embebido de uma modernidade cuja fonte de alimentação ideológica é o progresso e o desenvolvimento, agora denominado "sustentável" (e que, como já se cansou de afirmar, fez promessas de bem-estar e não as cumpriu); como parece um tanto pragmático, cujo objetivo maior é impedir maior exploração "dos que não sabem pelos que sabem". Exemplo disso é o esforço do presidente do STR que, imbuído de sincera preocupação com seus pares, apoiou-se em alguns poucos funcionários municipais e peregrinou de comunidade em comunidade, buscando formar turmas de educação de jovens e adultos para encaminhar reivindicação à prefeitura municipal. Então, a educação - tomada como escolarização - é vista pela entidade como um direito do cidadão e dever do Estado; uma possibilidade de tirar das trevas homens e mulheres que, em suas histórias, não puderam estudar no devido tempo. Ao mesmo tempo, o presidente parece esperar pouco ou satisfazer-se com pequenos resultados. Assim se refere à oportunidade de educação oferecida pelos recentes programas governamentais:

Houve uma luta muito grande pelo fato de que hoje, na medida em que você está reivindicando e tem ganhos e você não sabe ler, você tem que passar o poder para outra pessoa, pagar duas diárias para passar uma procuração. $\mathrm{O}$ sindicato também precisou muito de pessoas para fazer a chapa e tinham que saber ler, e eles são tirados das comunidades, e então foi uma dificuldade que a gente sentiu e sente porque as pessoas não têm como fazer um ofício, pois quem está na direção da associação de tudo isso precisa. Por exemplo, agora vem os projetos do PRONAF [Programa Nacional de Fortalecimento da Agricultura Familiar] é outra dificuldade, tem caboclo que não sabe ler, não sabe

ção no campo. Entendo que o sindicato, em que pesem fragilidades na ação organizativa e na luta pelos direitos, cumpre importante função na vida dos camponeses e encontra vigor na articulação que busca com as associações de pequenos agricultores. 
assinar o nome e pra tirar semente, pra tomar aquele cartãozinho de financiamento do governo, tem que assinar o nome e não assinando quem sabe se aquele dedo é mesmo dele , porque em todo setor existe má fé [...] Eu sempre digo pro pessoal: tem que estudar, pois com o estudo o que você aprende, ninguém rouba, eu sempre digo isso. Rouba um relógio, um óculos, qualquer coisa, mas o que você aprende não rouba e hoje o que prevalece é o estudo; o estudo está na agricultura, está em criar uma galinha, pra criar uma galinha tem que ter estudo. (Aldemir, presidente do STR de Baturité, cursou até $3^{\text {a }}$ série, a qual freqüentou por três vezes porque não havia a $4^{\mathrm{a}}$ série)

Excetuando as associações e o STR, essas instituições - Estado e mercado - são personagens nebulosos nas vidas do Sr. Vicente ou de Dona Nenê. Nebulosos porque raramente os trabalhadores rurais das comunidades identificam as responsabilidades ou atribuições de cada uma. Curiosamente, porém, eles próprios parecem repetir um discurso veiculado cotidianamente por elas - o de que se, com estudo, conseguir um emprego já é difícil; sem estudo, a dificuldade torna-se ainda maior. Quando solicitados a falar o que sabem sobre os programas a que tiveram acesso Alfabetização Solidária, Brasil Alfabetizado, Fundamental de $1^{\mathrm{a}}$ a $4^{\mathrm{a}}$ etc. -, sobre quem ou qual instituição tomou a iniciativa de oferecer os programas que freqüientam, esses trabalhadores não respondem com segurança; é comum remeterem toda a responsabilidade à prefeitura - no caso, ao Estado representado pelo governo municipal -, o que é compreensível, pois são os governantes locais que têm mais proximidade com a vida das comunidades, além das entidades associativas. E terminam indagando "É isso mesmo?", como se estivessem sendo sabatinados pela pesquisadora.

Nos conselhos gestores municipais que supostamente representariam espaço político de disputa do fundo público - por exemplo, no Conselho Municipal de Educação ou do FUNDEF (Fundo de Manutenção e Desenvolvimento do Ensino Fundamental e de Valorização do Magistério), agora FUNDEB (Fundo de Manutenção da Educação Básica) e o STR -, os trabalhadores têm direito a enviar seu representan- te. No entanto, esses mecanismos de participação não são vistos nem apropriados pelos trabalhadores rurais como arenas de disputa que, se ocupadas por interesses em conflito, podem fundar uma esfera de discussão pública das políticas governamentais e das demandas sociais. Há uma avaliação, especialmente feita pelas lideranças sindicais, de que os conselhos são meros espaços de homologação das propostas dos governantes. Assim, não acompanham as decisões que, eventualmente, aí são tomadas.

Já as associações - das quais os entrevistados, em sua maioria, são sócios -, se não são vistas como diretamente responsáveis pela existência dos programas educacionais nas comunidades, são identificadas como espaços que empreendem certo esforço para trazer melhorias e, dentre elas, a escola, um programa ou o transporte escolar para os que precisam estudar na cidade. Porém, em se tratando da educação, o reconhecimento de esforços incansáveis incide sobre uma instituição de feições particulares e não na arena política. Aqui, fazendo jus a nossa tradição cultural personalista (Holanda, 1995), nenhuma instituição merece mais crédito do que a professora ou o professor. Eles aparecem como os atores mais importantes na experiência desses trabalhadores educandos. Muitos relatos expressam a gratidão e o respeito profundo pelo esforço da professora Lúcia ou da professora Isabel, que passaram de casa em casa para incentivar ou convencer uns e outros para o início ou o retorno aos estudos. Note-se que o presidente do STR também se mobilizou para isso, todavia, a professora é vista como mais desprendida, sem interesses políticos. É verdade que alguns comentam que ela também tem interesse no "salário", mas isso não se dá em detrimento do reconhecimento de seu empenho; chegam mesmo, amiúde, a emitir avaliações um tanto generosas das condições ou da qualidade do ensino:

Tem livro, tem caderno, tem caneta, tem tudo. Acho que pra mim não tá faltando nada, não. Tá bom demais. A Professora Lúcia é boa demais (...) Gostamos muito dela. Acho que é o jeito como ela trata a gente. Eu sonho uma 
professora daquela pra minha filha. Porque se a gente adulta ela trata assim, avalie criança, né? (Maria Auxiliadora, 34 anos, Sítio Jesuítas, Fundamental I - $3^{\mathrm{a}}$ e $4^{\mathrm{a}}$ séries)

A Vanúsia ensina, dá a lição, tudo é satisfeito com ela, não querem outro professor, querem é ela. Porque as letras que os meninos não sabem fazer, ela vai e ensina tudinho. Ela tem a paciência de ensinar, analfabeto de tudo que não sabe de nada, ela ensina letra por letra. Aí, ninguém vai dizer que ela é ruim. (Dona Nenê, 61 anos, Sítio Candeia Boa Vista)

Observou-se não ser tudo tão satisfatório: na escola da Professora Lúcia, o quadro negro estava quebrado, a professora trabalhava com material inadequado, pois é o utilizado no período da manhã com as crianças do Ensino Fundamental I; exerce também a função de merendeira da turma no horário da aula; sua qualificação é precária, posto que a "capacitação" para o trabalho foi feita apenas em dois dias no início do ano letivo; já não possuía mais cartolina para preparar a aula do dia seguinte; e assim por diante. No que concerne às práticas pedagógicas, as observações em sala de aula, as conversas informais e as entrevistas trouxeram para o estudo a constatação de uma inadequação de metodologias e do material didático; uma insuficiência absurda na formação dos professores das escolas rurais de educação de jovens e adultos e nas instalações físicas. Uma indagação: tal quadro tem condições de conduzir um processo educacional com efetiva aprendizagem?

A despeito dessas precariedades, os estudantes valorizam a escola e o estudo, tecem apreciações favoráveis aos cursos que freqüentam. Todos eles. Por quê? O que determina semelhante idéia acerca de suas experiências educacionais? Arrisco uma explicação enveredando por duas dimensões: uma relacionada a ganhos que não se referem somente ao aprendizado da leitura e da escrita, mas à ampliação da vida social, ou seja, à possibilidade de uma sociabilidade mais alargada e prazerosa; outra dimensão estaria vinculada ao direito, à singularidade de sua construção em nossa sociedade.

\section{Uma vereda: a ampliação da vida social}

A vida nas comunidades rurais certamente não se restringe ao mundo do trabalho árduo. Ainda que as pessoas entrevistadas se apresentem como sujeitos, cujas vidas estão imersas em dificuldades ou em precariedades materiais, há toda uma rede de relações e práticas - religiosas, políticas, de vizinhança - que emprestam sentido ao cotidiano. Freqüentar uma sala de aula, receber atenção quase individualizada de uma professora, conversar e ter contato com temas novos, tudo isso, segundo os depoimentos dos trabalhadores e trabalhadoras rurais, faz-os satisfeitos. Vejamos o que diz Maria Auxiliadora, que voltou a estudar porque desejava ajudar os filhos pequenos nas tarefas escolares e, como não o conseguia, dizia ficar muito tensa:

Depois que voltei a estudar melhorou o meu estresse; às vezes eu ficava muito estressada; quando chego aqui, acaba tudo! Às vezes eu saio de casa cansada, assim com uma raiva, mas quando eu piso aqui, acabou-se! (Maria Auxiliadora, 34 anos, Sítio Jesuítas, Fundamental I - $3^{\text {a }}$ e $4^{\mathrm{a}}$ séries)

Sr. Ernando voltou a estudar depois de passar 30 anos "sem pisar em uma sala de aula". Freqüentou o Fundamental I há uns três anos e agora voltou para a mesma série porque tem dificuldade para ler e escrever e quer ver se "pega o ritmo mais um pouquinho". Acerca da experiência em sala, comenta:

Quando a gente vai pra uma sala de aula a gente pega muito conhecimento. Quando a gente começa a gente sente dificuldades, mas quando começa a pegar mais intimidade, aí você começa a achar bom. Tem os amigos que a gente fica conversando com eles e tudo o mais. Ali é divertimento pra gente; é um passatempo. Além de a gente aprender alguma coisa, é um passatempo. (Sr. Ernando, 44 anos, Sítio Candeia Boa Vista, Fundamental I - $1^{\mathrm{a}}$ e $2^{\mathrm{a}}$ séries) 


\section{Outra vereda: o direito à educação}

Os depoimentos até aqui são claros. Mas quanto ao direito? Como identificar se está a se construir o direito à educação ou se os estudantes têm a percepção - nem me refiro à "consciência" - de que direitos estão sendo ou podem ser criados com sua participação?

Avalio que não é possível tal identificação se a análise pautar-se somente nos depoimentos. É recomendável que se examinem igualmente as práticas, pois se a pesquisa limitar-se a reproduzir as falas dos sujeitos e não interpretá-las, considerando outros tantos fatores - procedimento que persegui até aqui -, o estudo resultará em mero retrato sem análise.

No meu entender, o percurso do direito que se vem buscando instituir, em consonância com a Carta Constitucional de 1988, encontra-se em estágio muito embrionário; ele é muito presente nos propósitos e no discurso e praticamente ainda ausente da realidade educacional, ou seja, o direito é proclamado à exaustão, mas não é exercido na sua condição de direito humano. Com isso quero dizer que, concebida como direito humano, a educação é direito indivisível, o que significa que deve ser exercido em sua totalidade - por exemplo, além da garantia de vagas, o ensino deve ter qualidade $\mathrm{e}$ atender às necessidades e às especificidades dos diferentes grupos sociais. Além dessas características, o direito humano é interdependente e "justiciável", ou seja, todos os direitos são igualmente importantes e só podem ser exercidos se todos os outros são respeitados e como não são concessões ou gentilezas estatais podem ser exigidos na Justiça (Graciano, 2005).

Essa é uma concepção de direito que nos permite colocá-lo na ótica da sociedade e não somente do Estado. É uma concepção que relaciona o direito não somente às garantias inscritas nas leis e nas instituições, mas coloca-o em sintonia com a idéia de que na sociedade pode estar sendo produzida a compreensão de que todos temos direito a ter direitos.

Assim, é possível afirmar que sociedade civil e Estado são dois campos de atuação e defesa do direi- to humano à educação. Com isso quero dizer que o Estado pode ser compreendido como um espaço contraditório, um espaço no qual forças várias disputam a hegemonia, isto é, disputam a direção das suas políticas, não se tratando, portanto, de um bloco homogêneo. Também não-homogênea e com suas particularidades e contradições é a vida da sociedade civil. Aqui, ideologias e interesses diversos são veiculados. Quando os interesses são comuns a um determinado grupo e este torna-os reivindicações, configuram-se os movimentos sociais que, no âmbito da sociedade civil, produzem mobilizações, disputam o fundo público, o ponto de vista cultural, moral ou político.

Ainda que precária, a escolarização que se vem processando pode até estar caminhando na direção da instituição do direito à educação. $\mathrm{O}$ trabalhador rural avalia esse processo, ainda que com ambigüidades, com os elementos que consegue reunir a partir de seu dia-a-dia e de suas memórias. Para ele, antes, quando criança, há cerca de três décadas, tudo era muito mais difícil, havia menos ofertas de programas governamentais, portanto, de oportunidades educacionais. Hoje, embora persistam tantas insuficiências, $a$ educação é para todos, só não estuda quem não quer!

Indago, porém: que universalidade é essa? $\mathrm{O}$ direito, para fazer jus ao conceito, deve ser universal, e se não é para todos é privilégio. Se esse direito está chegando tão desigualmente, tão incompleto, com a qualidade tão comprometida, a pergunta inicial mantémse: a isso pode denominar-se direito?

Bobbio (1992, p. 4) já nos alertava que os direitos são históricos, nascidos de forma gradual, "nem todos de uma vez, nem de uma vez por todas". E "nascem quando devem ou podem nascer" (idem, p. 7). Em concordância com Bobbio, eu acrescentaria, ainda, que nessas paragens os direitos demoram a florescer, custam para sair do papel. Parece-me difícil afirmar com todas as letras que os trabalhadores rurais instituem o direito à educação. O que se configura na experiência em estudo, na verdade, encontra-se mais próximo da destituição do direito assegurado pela Carta Magna do que da construção. Por que o direito não floresce? Por que não é usufruído ou exercido? Essa 
pergunta pode ser transformada em questão de investigação para aprofundamento futuro deste estudo.

É possível, com dose de boa vontade, reconhecer que os programas pretendem dar respostas às exigências do novo momento em que vivemos - de uma economia que cada vez mais inclui marginalmente populações ou grupos sociais, como os trabalhadores rurais - com ofertas, ainda que precários, de "políticas públicas", que sempre foram implementadas como dádivas de governantes.

Entendo que, para o florescimento e exercício de direitos, a sociedade civil e os grupos que os demandam precisam tornar-se força social e política para disputá-los na esfera pública, pois é nesse âmbito que as carências alcançam visibilidade, são ouvidas e reconhecidas como direitos. Tornar-se força que redefina o núcleo do problema educacional no campo, encravado na questão agrária, mãe das desigualdades no campo e na cidade; força que também redefina a situação do município brasileiro, esfera administrativa e política cujos aportes financeiros para a educação não acompanham as responsabilidades estabelecidas pelas reformas educacionais recentes e cuja sociedade civil organizada nem sempre consegue escapar dos fios que tecem a dependência e o clientelismo.

Falta-nos a experiência republicana de um Estado que defina políticas efetivamente públicas, ou seja, democráticas, transparentes e universais. E, pensando que o Estado é sociedade política e sociedade civil, apontaria mais uma "falta", já que ainda não conseguimos sair do quadro "em negativo": falta-nos, como sociedade civil, organizarmo-nos de forma a educar não somente nossos pares, os movimentos sociais, mas também a sociedade política, o Estado, interferindo nas políticas governamentais - seja ocupando espaços, como os conselhos municipais, seja interpelando judicialmente suas ausências, como já o fazem determinados movimentos.

É mister recompor esse Estado com forças efetivamente democráticas, aprofundando processos educativos que constroem direitos. E os espaços públicos - associações, conselhos, sindicatos, fóruns vários (de educação de jovens e adultos, comitês em defesa do direito à educação pública etc.) - podem e devem ser apropriados pelos trabalhadores rurais, de modo a elaborar propostas e fortalecer mobilizações, pois, como já mencionei, propostas são negociadas se houver população mobilizada. Consideradas essas proposições, penso, então, que os direitos podem ser construídos no campo. Um longo caminho, porém, resta ainda ser percorrido.

\section{Referências bibliográficas}

BOBBIO, Norberto. A era dos direitos. Rio de Janeiro: Campus, 1992.

BRASIL. Constituição da República Federativa do Brasil. Fortaleza: Banco do Nordeste do Brasil, 1988.

BRASIL. Ministério da Educação. Referências para uma política nacional de educação do campo. Brasília: Ministério da Educação, 2004.

DAGNINO, Evelina. Os movimentos sociais e a emergência de uma nova noção de cidadania. In: DAGNINO, E. Anos 90: política e sociedade no Brasil. São Paulo: Brasiliense, 1994.

FASHEH, Munir. Como erradicar o analfabetismo sem erradicar os analfabetos? Revista Brasileira de Educação, n. 26, p. 157169, maio-ago. 2004.

GRACIANO, Mariângela (Org.). Educação também é direito humano. São Paulo: Ação Educativa \& Plataforma Interamericana de Direitos Humanos, Democracia e Desenvolvimento, 2005.

HOLANDA, Sérgio Buarque de. Raízes do Brasil. 26. ed. São Paulo: Companhia das Letras, 1995.

INSTITUTO PAULO MONTENEGRO; AÇÃO EDUCATIVA. Indicador nacional de Alfabetismo Funcional: um diagnóstico para a inclusão social. São Paulo: Instituto Paulo Montenegro/Ação Educativa, 2001.

MARQUES, Cláudio de Albuquerque; AGUIAR, Rui Rodrigues; CAMPOS, Márcia Oliveira Cavalcanti. Avaliação do nível de alfabetização das crianças matriculadas na $2^{a}$ série das escolas públicas do estado do Ceará. Fortaleza: UFC, 2006, mimeo.

MARTINS, José de Souza. A sociabilidade do homem simples: cotidiano e história na modernidade anômala. São Paulo: Hucitec, 2000 .

PEREIRA, Sônia. A contribuição do homem simples na construção da esfera pública: os trabalhadores rurais de Baturité - Ceará. Revista Brasileira de Educação, n. 26, p. 29-43, 2004. 
DI PIERRO, Maria Clara de. Seis anos de educação de jovens e adultos no Brasil: os compromissos e a realidade. São Paulo: Ação Educativa, 2003.

RANCIÈRE, Jacques. O desentendimento: política e filosofia. São Paulo: Editora 34, 1996.

SOARES, Magda. Letramento: um tema em três gêneros. Belo Horizonte: Autêntica, 2003.

TELLES, Vera da Silva. Direitos sociais: afinal, do que se trata? Belo Horizonte: UFMG, 1999.

XIMENES, Salomão Barros. Fundo público e direito à educação: um estudo a partir dos gastos públicos da União e do Município de Fortaleza. 2006. 199p. Dissertação (Mestrado em Educação) Faculdade de Educação, Universidade Federal do Ceará, Fortaleza, 2006.

SÔNIA PEREIRA BARRETO, doutora em ciências sociais pela Pontifícia Universidade Católica de São Paulo, é professora da Faculdade de Educação da Universidade Federal do Ceará, atuando na graduação em pedagogia e no Programa de Pós-Graduação em Educação. Publicações mais recentes: O significado do analfabetismo e do letramento para trabalhadores rurais: construindo uma compreensão do direito à educação. In: ZENAIDE,
Maria de Nazaré T.; DIAS, Lúcia Lemos; TOSI, Giuseppe; MOURA, Paulo V de. (org.). Formação de direitos humanos na universidade: ensino, pesquisa e extensão. (João Pessoa: Editora Universitária, 2006); A experiência de trabalhadores rurais no Conselho Municipal de Desenvolvimento Sustentável: oferta do estado e aprendizado da fala. (Trabalho apresentado na REUNIÃO ANUAL DA ANPEd, 28. 2005, Caxambu, Anais... Caxambu, 2005, I CD-ROM); A experiência de escolarização de trabalhadores rurais em Baturité - Ceará: a construção ou destituição do direito à educação no campo? (Trabalho apresentado na REUNIÃO ANUAL DA ANPEd, 29. 2006, Caxambu, Anais... Caxambu, 2006, I CDROM); A contribuição do homem simples na construção da esfera pública: os trabalhadores rurais de Baturité - Ceará (Revista Brasileira de Educação. v. 26, p. 29-43, 2004); A esfera pública e a cidadania: a árdua construção dos trabalhadores rurais de Baturité Ceará. In: MATOS, Kelma. (org.). Movimentos sociais, educação e escola: a favor da diversidade (Fortaleza: Edições UFC, 2004, p. 238-251). Pesquisa em andamento: “A construção do direito à educação: significados do letramento para trabalhadores rurais". E-mail: soniapbarreto@uol.com.br

Recebido em março de 2007 Aprovado em abril de 2007 